\title{
Autolycism in the Foraging of the Grey-headed Green Woodpecker (Picus canus)
}

\author{
Shigeru Matsuoka* \\ ヤマゲラ (Picus canus)の採慨にみられる \\ オートライシズムについて \\ 松岡茂
}

\begin{abstract}
北海道大学苫小牧地方演習林において, 冬期間, ヤマゲラがクマゲラの食こんについて採慨するのがしばし ば観察された. ヤマゲラのこの行動はオートライシズムの定義に一致する.一般に, ヤマゲラは, クマゲラが 採餌を終えて去った後に，その食こんについて採飭を行なった。しかし，ヤマゲラが大きな羽音をたててクマ ゲラを追い, その食こんについた例が 1 度だけ観察された．クマゲラは倒木などに hammering の方法で大きな 穴を開けて採飭するが, ヤマゲラはこの穴をさらにUろげることはなく, 通常の採飭と同じ方法である probing やgleaningによって採餌した.このようなヤマゲラのオートライシズムは, 降雪地域におけるヤマゲラの冬期 間の生存に有利であろう.
\end{abstract}

Autolycism denotes the use that birds make of other species of animals in ways that are not strictly parasitic, commensal, or symbiotic (THOMSON, A.L., ed. 1964. A new dicrionary of birds). The following behavior of the greyheaded green woodpecker (Picus canus) seems to be a case of autolycism. It was observed on 13th December, 1973 in the Tomakomai Experiment Forest of Hokkaido University, which is located in the south-central part of Hokkaido. The study area mainly consists of natural broad-leaved woods.

A female black woodpecker (Dryocopus martius) was opening a large hole on a log by hammering to forage for ants (Camponotus obscuripes). As soon as she flew away by the approach of the author, a female grey-headed green woodpecker landed on the log and began to forage by probing and gleaning into the same hole (time 13:30).

The same black woodpecker began to forage on another $\log$ about 100 meters away (13:43). A female grey-headed green woodpecker (it was not clear whether she was the same individual as mentioned above) came in flight and landed on a shrub about 2 meters away from the log (13:45). The female grey-headed green woodpecker once went out of sight, but when the black woodpecker stopped foraging and flew to a tree trunk near the log $(14: 01)$, the former returned to the same shrub on which she had perched before $(14: 02)$. As the black woodpecker flew to another tree a little farther away, the grey-headed green woodpecker landed on the log immediately and began to forage by means of probing and gleaning (14:03). Then the greyheaded green woodpecker had to leave, since the black woodpecker returned and began to forage upon the same log (14:05).

The grey-headed green woodpecker was found perching on the top of a tree about 30 meters away from the log on which the black woodpecker had foraged (14:15). When the greyheaded green woodpecker flew to the shrub near the log, making louder fluttering sounds than in usual flight (14:17), the black woodpecker flew to a tree trunk 1 meter away from the $\log$ and became still, as when a sparrow hawk (Accipiter nisus) flew over the woods. The grey-headed green woodpecker landed on the log in a moment and began to forage again $(14: 18)$. But she was supplanted when the black woodpecker flew back and to forage on the same log (14:19).

Although this kind of foraging behavior of grey-headed green woodpeckers has often been observed during the winters (November to April)

* Institute of Applied Zoology, Faculty of Agriculture, Hokkaido University, Sapporo 060

北海道大学農学部応用動物学教室（干060 札幌市北区北 9 条西 9 丁目） 
of 1973 to 1976 in the Tomakomai Experiment Forest, the above case was the only instance that a black woodpecker was driven away from the foraging site by the unusually loud fluttering sounds of the grey-headed green woodpecker. Furthermore, the author observed a case in which a male grey-headed green woodpecker drove a male white-backed woodpecker (Dendrocopos leucotos) away from a foraging site on 17th October 1974.

The foraging sites of both sexes of black woodpeckers were exploited by grey-headed green woodpeckers regardless of sex. Greyheaded green woodpeckers would appear at the foraging sites of black woodpeckers (1) flying together with the latter, (2) when the latter perched in a high tree top before foraging, or (3) while the latter was foraging on the tree trunk or log. In many such cases grey-headed green woodpeckers were foraging or resting on the tree trunks close to the foraging sites of black woodpeckers, or were foraging on the same tree trunk (or $\log$ ) together with the black woodpeckers until the latter left the foraging site. Usually one black woodpecker was followed by one greyheaded green woodpecker, but the author once observed that three individuals of the latter followed the former, on 22nd January 1976. Then a female grey-headed green woodpecker foraged first at the feeding site of a male black woodpecker, after he left; she was soon supplanted by another female and the latter was easily displaced almost immediately by a male.

According to my observations in this forest, black woodpeckers mainly foraged on logs, stumps, and large dead tree trunks by opening big and deep holes by hammering. On the other hand, grey-headed green woodpeckers chiefly foraged on the bark surface, crevices, tree holes and other damaged parts of a tree by means of probing and gleaning and, also picked up tree seeds (Rhus ambigua and Schsandra chinensis, and so on) in winter season. As mentioned above, grey-headed green woodpeckers foraged by probing and gleaning on sites where black woodpeckers had dug and were never observed to widen the hole by pecking or hammering.

An analysis of feces from the winter season showed that black woodpeckers mainly fed on ants (especially Camponotus spp.), while greyheaded green woodpeckers mostly fed on tree seeds, ants (including Camponotus spp.) and some coleopteran insects (MATSUOKA, unpublished). It is possible that the ants were derived partly from autolycic foraging. It seems to me that autolycism in grey-headed green woodpeckers, which usually forage by probing and gleaning, is advantageous to their survival in winter in snowy districts, since snowcover will reduce their foraging spaces.

Although this kind of autolycism among the palaearctic species of woodpeckers has not yet been described (D. BLUME, personal communication), it may be expected between the black woodpecker and the grey-headed green woodpecker (or green woodpecker, Picus viridis, which is similar to the grey-headed green woodpecker in foraging behavior). As I have not observed the foraging behavior of the two woodpecker species in the breeding season, it is not clear whether autolycism in the grey-headed green woodpecker is found throughout a year or only in winter.

The author is very grateful to Dr. Dieter BLUME for making valuable suggestions on the behavior of woodpeckers, and to Dr. Hisashi ABE, Dr. Kenkichi IsHIGAKI, and Dr. Fred C. ZWICKEL for critically reading the manuscript. 